\title{
Analisis Sensor Arus Invasive ACS712 dan Sensor Arus Non Invasive SCT013 Berbasis Arduino
}

\author{
Wayan Arsa Suteja \\ Politeknik Nasional Denpasar \\ Denpasar - Indonesia \\ 4rs41982@gmail.com
}

\author{
Adi Surya Antara \\ Politeknik Nasional Denpasar \\ Denpasar - Indonesia \\ adisuryaantara.huawei@gmail.com
}

\begin{abstract}
The electric load measurement system is a device designed to measure and monitor electricity consumption. In this research, the comparison process of reading the electric current uses the Non-Invasive current sensor model SCT013 and the Invasive current sensor model ACS712 which is connected to the load of electricity consumption. The microcontroller used is the Arduino Microcontroller which functions as the main control system that will be connected to the computer. With the aim later to be able to determine which current sensor is suitable and accurate in reading the electric current. By conducting experiments on the variables of two current sensors, in order to obtain the results of the comparison of the measurement and monitoring of the non-invasive current sensor model SCT013 with the Invasive current sensor model ACS712. Researchers hope to get how much the error percentage value or error of two non-invasive current sensors model SCT013 with Invasive current sensor model ACS712, so that later we can find the right sensor to get the right data for measuring tools, and can be used to monitor energy consumption. electricity that we use.
\end{abstract}

Keywords - Mikrokontroler Arduino, current sensor SCT013, digital clamp meter, current sensor ACS712

\section{PENDAhUluan}

Pada saat ini dunia teknologi berkembang dengan pesat di segala bidang. Dengan semakin majunya ilmu pengetahuan dan ilmu teknologi saat ini ditandai dengan banyak bermunculnya alat-alat yang menggunakan sistem kontrol digital dan automatisasi [8]. Di era globalisasi sekarang ini, teknologi sangat membantu aktivitas manusia agar lebih mudah dan lebih efisien. Teknologi alat elektronika adalah salah satu teknologi yang tentunya akan sangat membantu manusia dalam melakukan berbagai hal terutama dalam mengontrol pemakaian listrik [8].. Salah satu sistem kontrol sederhana untuk mengukur penggunaan listrik yang bisa kita kembangkan yaitu sistem kontrol berbasis arduino dengan menggunakan sensor arus, yaitu sensor arus non invasive model SCT013 dan model sensor arus invasive ACS712. Dengan menggunakan sistem kontrol berbasis arduino ini, diharapkan mampu mendapatkan hasil pengukuran yang tepat dan sesuai.

Dari sensor tersebut nantinya akan didapatkan kekurangan dan kelebihan, didalam memperoleh hasil pengukurannya. Terkait dengan adanya kekurangan dan kelebihan dari sensor tersebut pada studi kasus ini, maka diperlukan sebuah metoda perbandingan seberapa besar nilai presentase kesalahan atau error dari perbandingan alat ukur, baik itu sensor arus ACS712, sensor arus SCT013 terhadap alat ukur digital clamp meter. Dengan diperolehnya hasil kesalahan atau error ini, diharapkan mampu mendapatkan alat sensor arus yang tepat, didalam melakukan pembacaan pemakaian arus listrik sehingga nantinya mampu memonitoring pemakaian listrik dan bisa menghitung biaya pemakaian sistem kelistrikannya dengan benar dan sesuai dengan hasil monitoring yang didapatkan.

Beberapa penelitian terkait monitoring pemakaian energi listrik telah dilakukan, baik dalam cakupan beban kecil seperti rumah tangga sampai dengan cakupan beban yang besar seperti distribusi penyaluran daya PLN. Penelitian pertama dengan judul "Perancangan Prototype Sistem Control dan Monitoring Pembatas Daya Listrik Berbasis Mikrokontroler "[8]. Penelitian ini menggunakan mikrokontroller ATMEGA16 sebagai alat pemrosesan sinyal ADC, sensor arus ACS712 yang bisa difungsikan sebagai sensor arus AC maupun DC, LCD sebagai pemberi tampilan informasi, Keypad sebagai pemberi sinyal pada rangkaian yang sudah dibuat untuk monitoring energy listrik, relay sebagai pemutus arus, yang kerjanya digerakan oleh driver relay itu sendiri, dan buzzer yang berfungsi sebagai loud speaker untuk penanda alarm pada rangkaian yang dihubungkan. Keenam komponen elektronika tersebut dirangkai ankan menjadi suatu sistem monitoring dan control otomatis pada pemakaian daya listrik di rumah. Dengan alat control dan monitoring ini pemakaian daya listrik di rumah menjadi termonitoring pemakaiannya serta konsumsi yang berlebihan dari masing masing beban bisa dihentikan jalannya arus listrik ke beban [8].

Penelitian kedua dengan judul "Pengukuran Daya Listrik Real Time Dengan Menggunakan Sensor Arus ACS712" [8]. Penelitian ini membahas tentang pengukuran daya listrik dengan penggunaan 


\section{Analisis Sensor Arus Invasive ACS712 dan Sensor Arus Non Invasive SCT013 Berbasis Arduino}

mikrokontroller ATMEGA16, sensor arus ACS712 dan MCB yang dilengkapi pengaman thermos difungsikan sebagai pengaman beban lebih, yang dilengkapi relai elektromagnetik untuk pengaman arus hubungan singkat. Pemasangan mikrokontroller ATMEGA16, ACS712 dan MCB dilakukan pada industry kecil untuk memonitoring naik turunnya tegangan dan factor daya. Dengan adanya alat monitoring dan control ini, industry kecil dapat mengetahui dan mengurangi kerugian daya yang dikeluarkan serta menghemat pemakaian energy. Adapun kategori industry kecil yang dipasangkan alat ini adalah industry kecil yang berdaya 450 watt sampai 2200 watt dan bertegangan 1 fase [8].

Penelitian ketiga dengan judul "Rancang Bangun Sistem Monitoring Listrik Prabayar Dengan Menggunakan Arduinouno [8]. Penelitian ini membahas perancangan sistem monitoring listrik prabayar menggunakan sistem control ATMega8, sensor arus ACS712, web service, modul relay, dan jaringan internet. Sistem control ATMega 8 difungsikan sebagai control dan pengolahan sinyal dari sensor arus yang terpasang pada setiap kamar dan meneruskan informasi yang ada ke database web service, sensor arus ACS712 difungsikan untuk pengambilan data ampere dari setiap kamar, modul relay difungsikan sebagai sakelar elektrik yang memutus daya listrik ketika pulsa listrik tidak mencukupi. Masing-masing sensor akan terhubung langsung dengan peralatan listrik yang sedang on, beban listrik akan dihitung oleh sensor dan akan diolah oleh Mikrokontroller Arduino Uno untuk selanjutnya diolah pada server sehingga kebutuhan listrik secara real-time dapat dihitung. Untuk membandingkan keakurasian dari sensor, tiap-tiap perangkat akan diukur bebannya dengan Multimeter secara langsung dan hasil keduanya akan dibandingkan [8].

Penelitian keempat dengan judul "Kalibrasi Tegangan Pada Wattmeter Dengan Sensor Arus Seri ACS712 Berbasis Mikrokontroller ATM 8535" [8]. Penelitian ini membahas tentang pembuatan rangkaian alat yang difungsikan sebagai pengukur watt secara digital yang dapat dipergunakan secara portable. Adapun komponen yang dipergunakan pada penelitian ini antara lain sensor arus ACS712 sebagai pengukurarus AC, mikrokontroller ATmega8535 sebagai pembaca arus dan penghitung besaran daya, display LCD yang digunakan dan difungsikan sebagai penampil proses input dan output, perangkat beban seperti bohlam, dan regulator sebagai penstabil tegangan jala jala dari sumber PLN. Cara kerja alat adalah dengan membaca arus dengan sensor ACS712 dan tegangan yang lewat pada regulator, dengan besaran tegangan dan arus yang sudah diketahui tersebut nantikan dengan pemograman $\mathrm{C}$ pada mikrokontroler arduino hasil dayanya ditampilkan pada layar LCD [8].

Penelitian kelima dengan judul "Rancang Bangun Sistem Monitoring Arus Beban pada Gardu Distribusi
Menggunakan Short Message Service"[7]. Penelitian ini membahas sistem monitoring arus beban dimana merupakan perangkat yang diintegerasikan pada gardu distribusi. Nilai arus beban yang dibaca dan dikonversi oleh sensor, informasi waktu, dan tanggal secara real time ditampilkan pada LCD. Adapun komponen yang digunakan antara lain : Mikrokontroler Arduino Mega 2560, Modul IComSat v1.1-SIM900 GSM GPRS, Modul Micro SD Card, Modul RTC (Real Time Clock), power supply, LCD, dan Sensor Arus YHDC SCT 013000 1V. Pengimplementasian sistem monitoring arus beban dilakukan pada gardu distribusi KA-0298 yang menyuplai Laboratorium Teknik Elektro Universitas Udayana. Perangkat ini dapat melakukan monitoring arus beban berdasarkan perintah yang dikirimkan melalui SMS. Perintah SMS yang dikirim dengan kode "CEKARUS" dapat diterima dan direspon oleh sistem monitoring arus beban dengan hasil balasan SMS informasi nilai arus beban fasa $\mathrm{R}$, fasa $\mathrm{S}$, fasa $\mathrm{T}$ dan fasa $\mathrm{N}$ pada gardu distribusi. Sistem data logger pada perangkat dapat digunakan untuk merekam perubahan arus beban pada gardu distribusi. Sistem notifikasi arus beban memberikan SMS peringatan jika terjadi gangguan arus beban pada gardu distribusi [7].

Penelitian keenam dengan judul "Sistem Pencatatan Pemakaian Listrik Menggunakan Aplikasi Arduino" [9]. Penelitian ini membahas monitoring arus beban rumah tangga seperti lampu LED, lampu pijar, PC, charger HP, dispenser, dan laptop 12 inch yang diukur dengan sensor arus YHDC SCT013 yang diintegrasikan dengan mikrokontroller arduino dan rangkaian pendukungnya. Hasil dari monitoring sensor diperbandingkan dengan pengukuran digital clamp meter serta didapatkan persentase error yang rendah dari $0 \%$ sampai dengan $20 \%$ terhadap masing masing beban rumah tangga yang terpasang [9].

Berdasarkan keenam penelitian yang sudah dilakukan tersebut yang keseluruhannya mengangkat permasalahan monitoring energi listrik yang kita konsumsi setiap hari dan penelitian terdahulu tidak ada melakukan perbandingan dengan alat sensor yg lain serta belum ada nilai persentase kesalahan yg diperoleh dari alat sesnsor yg telah digunakan. Adapun topik yang akan penulis teliti dalam penelitian ini adalah berjudul "Analisis Sensor Arus Invasive ACS712 dan Sensor Arus Non Invasive SCT013 Berbasis Arduino". Dalam hal ini,penulis mencoba untuk menggunakan sensor arus yang bertipe non invasive seperti sensor arus SCT013 dan sensor arus Invasive ACS712. Penelitian tentang sensor arus tipe SCT013 dan ACS712 masih minim diteliti dan hal ini layak untuk dikaji lebih lanjut tentang akurasi maupun error yang di dapatkan ketika pengunaan kedua tipe sensor arus non invasive SCT013 maupun sensor arus invasive ACS712. Perlu diketahui bahwa setiap pembacaan sensor pempunyai perbandingan error yang berbeda beda sehingga perlu 


\section{Analisis Sensor Arus Invasive ACS712 dan Sensor Arus Non Invasive SCT013 Berbasis Arduino}

adanya perbandingan dengan kesesuaian hasil pengukuran, yang didapat melalui alat ukur arus seperti digital clamp meter. Hal ini perlu kita ketahui untuk melihat seberapa besar nilai persentase kesalahan atau error dari masing masing alat ukur arus invasive dan non invasive dalam memonitoring pemakaian energy listrik yang kita pergunakan..

Dengan diadakannya penelitian ini, didapatkan prototype dan perbandingan akurasi pembacaan masing masing sensor arus non invasive SCT013 dan invasive ACS712 sehingga didapatkan sensor yang tepat untuk mendapatkan hasil pembacaan pemakaian arus listrik dan pengguna mampu memonitoring pemakaian listrik dan bisa menghitung biaya pemakaian sistem kelistrikannya.

\section{TEORI DASAR}

\section{A. Mikrokontroller Arduino Uno}

Arduino adalah sebuah platform protoyping elektronik berupa perangkat keras dan lunak yang Open Source. Arduino Uno adalah tipe jenis Arduino yang cukup populer digunakan. Selain memiliki pin masukan dan keluaran yang banyak, Arduino jenis ini memiliki kapasitas memori yang lebih besar dibandingkan dengan beberapa jenis Arduino lainnya.Untuk ukuran dimensi perangkatnya Arduino Uno termasuk jenis Arduino dengan ukuran board yang besar

Arduino uno mempunyai 14 pin input output, mempunyai 6 output pwm dan 6 input analog, mempunyai cristal $16 \mathrm{Mhz}$ ceramic resonator. memakai Atmega328 sebagai mikrokontroler. Operating voltage 5 volt sehingga supply cukup dari USB laptop atau PC. Mempunyai $1 \mathrm{Rx}$ dan Tx untuk komunikasi serial dan tombol reset [1].

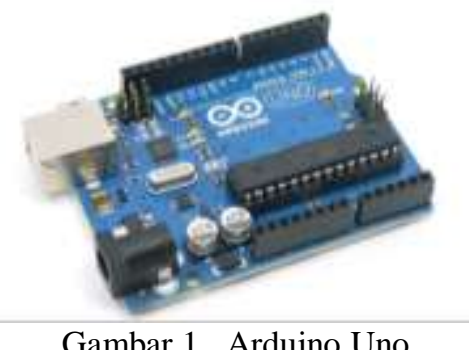

Gambar 1. Arduino Uno

\section{B. Sensor Arus Invasive ACS712}

Sensor arus ACS712 adalah merupakan sensor untuk mendeteksi arus, ACS712 ini memiliki tipe variasi sesuai dengan arus maksimal yakni 5A, 20A, 30A. ACS712 ini menggunakan VCC 5V. Cara kerja sensor ini adalah arus yang dibaca mengalir melalui kabel tembaga yang terdapat didalamnya yang menghasilkan medan magnet yang di tangkap oleh integrated Hall IC dan diubah menjadi tegangan proporsional. Ketelitian dalam pembacaan sensor dioptimalkan dengan cara pemasangan komponen yang ada didalamnya antara penghantar yang menghasilkan medan magnet dengan hall transducer secara berdekatan. Tegangan proporsional yang rendah akan menstabilkan Bi CMOS Hall IC yang didalamnya yang telah dibuat untuk ketelitian yang tinggi oleh pabrik. Gambar 2 merupakan sensor arus invasive ACS712 dengan arus maksimal sebesar 20 ampere [3] .

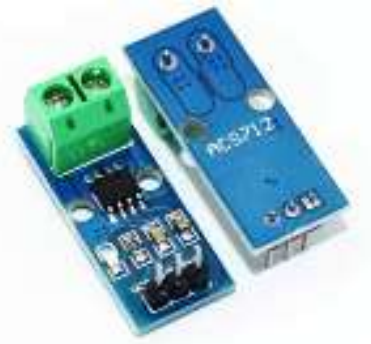

Gambar 2. Sensor Arus Invasive ACS712

\section{Sensor Arus Non Invasive SCT013}

Module sensor SCT013 tergolong ke current transformator sensor yang ditujukan untuk khusus mengukur arus bolak - balik atau Arus AC. Transformator arus dirancang untuk mendapatkan nilai arus sekunder yang lebih kecil dibandingkan sisi primernya sehingga aman untuk dilakukan pengukuran. Gambar 3 merupakan sensor arus non invasive SCT013 dengan batas arus yang diukur sebesar 20 ampere [ 9 ]

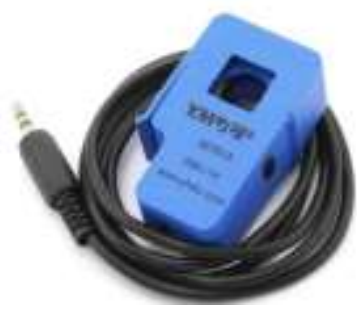

Gambar 3. Sensor Arus Non Invasive SCT013

\section{METODE}

Pendekatan dalam penelitian ini adalah pendekatan kuantitatif, karena penelitian ini banyak menampilkan angka angka. Hal ini menyesuaikan dengan penjelasan penelitian kuantitatif yang mana dituntut menggunakan angka, mulai dari pengumpulan data, penafsiran data, serta menampilkan data.

Adapun langkah langkah pada penelitian berikut, dapat dijelaskan pada Gambar 4. dapat dijelaskan bahwa semua proses dijalankan secara terurut dimulai dengan melakukan studi literatur pendukung sesuai dengan permasalahan penelitian dan dirangkum sebagai bahan acuan penulis. Kemudian menyusun kebutuhan apa saja yang harus dipenuhi dalam membangun sistem. Tahap berikutnya, dilakukan perancangan dan perakitan alat mikrokontroller baik itu software dan hardware. Proses dilanjutkan dengan analisa data pemograman mikrokontroller, implementasi hardware maupun implementasi software sesuai dengan perancangan. 


\section{Analisis Sensor Arus Invasive ACS712 dan Sensor Arus Non Invasive SCT013 Berbasis Arduino}

Proses selanjutnya setelah sistem selesai dibuat dilanjutkan dengan melakukan pengujian dan pencatatan sistem serta menganalisis hasil output yang diperoleh dengan memperbandingkan kedua tipe sensor arus tersebut. Langkah paling terakhir adalah menyusun laporan serta melakukan penarikan kesimpulan.

Pada tahapan analisa desain sistem, terdapat dua desain sistem yang dilakukan analisa mengenai proses pengambilan data yang terdapat dalam masing masing sensor arus invasive ACS712 dan sensor arus non invasive SCT013 yang akan dijalankan oleh sistem yang terdapat pada mikrokontroller arduino. Sensor arus invasive adalah sensor arus yang pemasangannya secara seri dengan rangkaian bebannya atau dengan kata lain terminal sensor arus dimasukkan kedalam bagian rangkaian yang menuju ke beban. Sensor arus non invasive adalah sensor arus yang proses pengukuran bebannya, terminal sensor arus tidak dimasukan ke dalam bagian rangkaian beban dan pembacaan arus beban dilakukan melalui proses pembacaan arus yang melalui kumparan pada sensor.

Alur analisis desain sistem akan dijelaskan pada Gambar 4, dengan tujuan alur proses sistem dapat lebih mudah dipahami. Berikut ini merupakan alur dari proses pengambilan data pada arus non invasive SCT013 yang terdapat pada sistem yang akan dibangun.

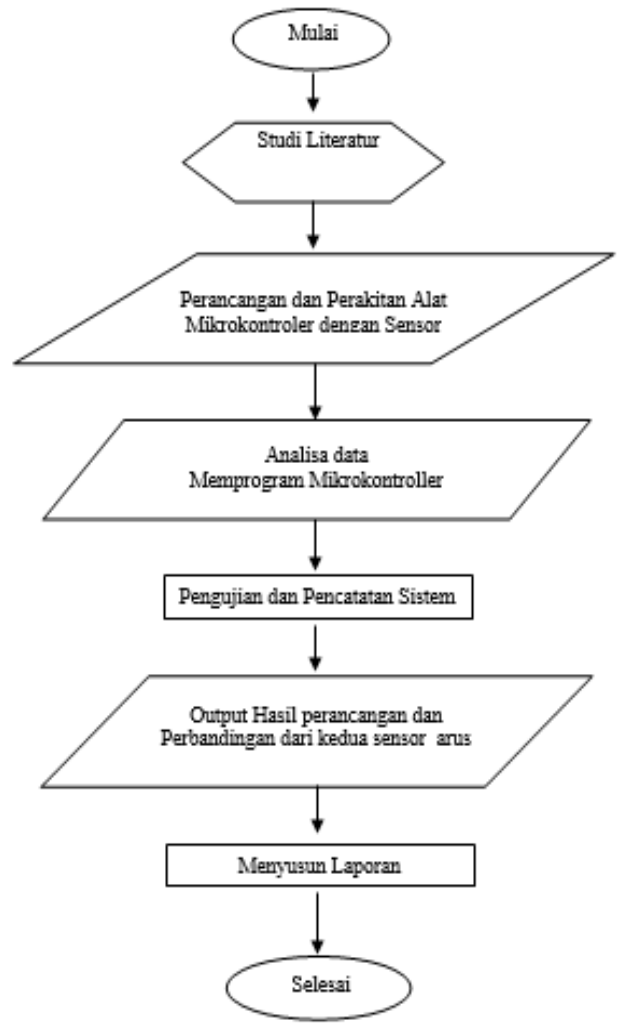

Gambar 4. Tahapan penelitian

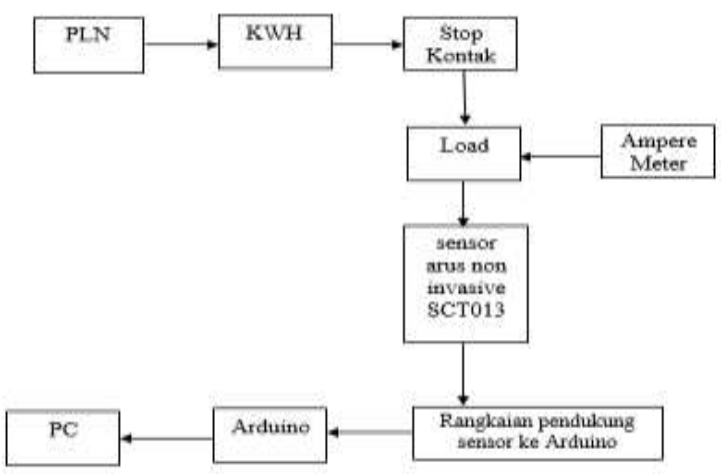

Gambar 5 Analisis Disain Sistem Sensor Arus Non Invasive SCT013

Cara kerja rangkaian seperti pada diagram blok pada Gambar 5 adalah sebagai berikut. Sumber daya utama didapatkan dari jaringan listrik PLN yang tersambung pada panel KWH meter. Panel KWH yang terpasang pada instalasi rumah tangga akan mendistribusikan penyaluran daya ke masing masing stop kontak. Sensor arus non invasive SCT013 memonitoring arus yang lewat dan sekaligus menampilkan arus yang dikonsumsi oleh beban yang terpasang. Selanjutnya, besaran arus dan daya dikalikan melalui pemrograman arduino maka hasil arus dan dayanya dapat di tampilkan pada layar PC. Fungsi rangkaian pendukung sensor ke arduino dalam diagram blok tersebut adalah sebagai pembantu proses konversi pembacaan ADC dari sensor arus non invasive SCT013 sehingga dapat dibaca dan diolah dengan baik oleh mikrokontroller arduino.

Analisis desain sistem sensor arus invasive ACS712 akan dijelaskan pada gambar 6. Berikut ini merupakan alur dari proses pengambilan data dari sensor arus invasive ACS712 yang terdapat pada sistem yang akan di bangun.

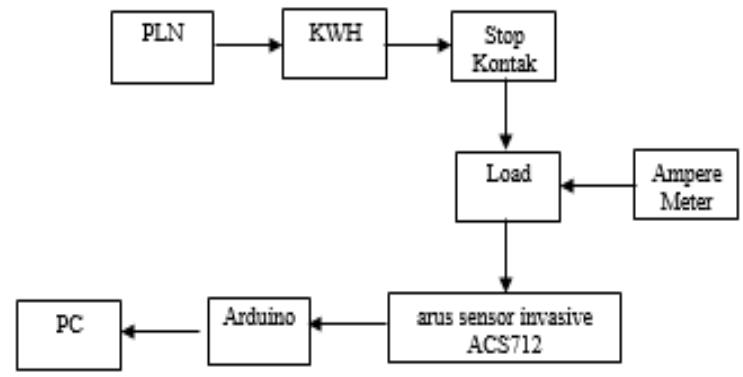

Gambar 6. Analisis Disain Sistem Sensor Arus Invasive ACS712

Cara kerja rangkaian seperti pada diagram blok pada Gambar 6 adalah hampir sama seperti desain sistem sensor arus non invasive SCT013, hanya dalam sistem sensor arus invasive ACS712, rangkaian pendukung sensor ke arduino tidak ada. Rangkaian pendukung 
merupakan rangkaian yang digunakan untuk membantu pembacaan peak current pada kumparan sensor arus non invasive SCT013 sehingga didapatkan pembacaan data analog untuk diteruskan ke perangkat arduino. Dapat kita lihat dalam desain load langsung terkoneksi ke input sensor arus invasive ACS712. Sumber daya utama didapatkan dari jaringan listrik PLN yang tersambung pada panel KWH meter. Panel KWH yang terpasang pada instalasi rumah tangga akan mendistribusikan penyaluran daya ke masing masing stop kontak. Sensor arus invasive ACS712 memonitoring arus yang lewat dan sekaligus menampilkan arus yang dikonsumsi oleh beban yang terpasang.

Terdapat skematik perangkat keras dari keseluruhan sistem yang terdiri dari beberapa komponen untuk membuat sebuah perangkat elektronik yang memonitoring pembacaan arus listrik. Mikrokontroler Arduino Uno akan disambungkan dengan sensor arus invasive ACS712 dan sensor arus non invasive SCT013 melalui rangkaian pembaca arus atau modul sebagai penghubung. Sensor arus arus non invasive SCT013 nantinya akan dihubungkan dengan kabel pada stop kontak untuk dapat membaca arus yang melewatinya, sedangkan pada sensor arus invasive ACS712 pada terminal inputnya akan disambungkan dengan kabel yang tersambung dengan source AC dan beban. Sistem mikrokontroller arduino uno ini akan bekerja ketika mendapat sumber daya melalui komputer atau laptop yang terhubung.

Untuk menghubungkan sensor arus invasive ACS712 dan sensor arus non invasive SCT013 ke Arduino Uno diperlukan koneksi yang berbeda dimana pada sensor arus invasive ACS712 tidak memerlukan komponen pendukung (sensor langsung dihubungkan ke mikrokontroler arduino uno) sedangkan sensor arus non invasive SCT013 memerlukan beberapa komponen sebagai sebuah rangkaian pendukung, komponen tersebut antara lain:

1. Resistor $33 \mathrm{Ohm}$ (didapat dengan perhitungan burden resistor)

2. Resistor $10 \mathrm{KOhm}$

3. Kapasitor 10 uf

4. Jack female $3,3 \mathrm{~mm}$

5. Kabel jumper

6. Papan PCB atau Breadboard

Berikut Gambar 7 rangkaian pendukung sensor arus ke arduino:

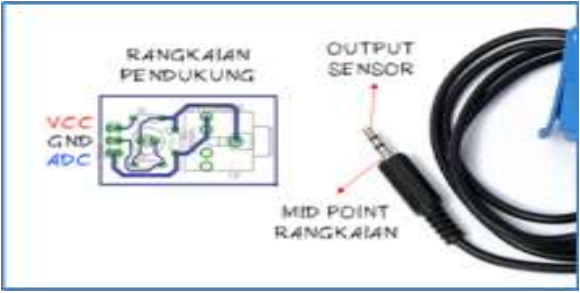

Gambar 7. Rangkaian Pendukung Modul Sensor Arus SCT013 ke Arduino Uno
Perhitungan burden resistor dilakukan untuk menentukan nilai resistor yang sesuai dengan spesifikasi sensor SCT013. Langkah-langkah perhitungan burden resistor akan dijelaskan sebagai berikut.

a. Menentukan arus maksimum yang akan dihitung. Pada sistem ini digunakan sensor arus SCT013 dengan nilai maksimum 100 Ampere.

b. Mengkonversi RMS arus maksimum menjadi peakcurrent, mengalikannya dengan $\sqrt{2}$. Primary peakcurrent $=$ RMS current $\times \sqrt{2}=100 \mathrm{~A} \times 1.414=$ 141.4 A

c. Membagi peak-current dengan jumlah putaran sensor arus untuk menentukan peak-current di kumparan sekunder. Sensor arus SCT013 memiliki 2000 putaran. Secondary peak-current $=$ Primary peak-current / no. of turns

$=141.4 \mathrm{~A} / 2000=0.0707 \mathrm{~A}$

d. Untuk meningkatkan resolusi pengukuran, tegangan yang melintasi resistor beban pada arus puncak harus sama dengan setengah dari tegangan referensi Mikrokontroller (AREF / 2). Pada sistem digunakan tegangan referensi di Arduino adalah sebesar $5 \mathrm{~V}$.

Ideal burden resistance $=(\mathrm{AREF} / 2) /$ Secondary peak-current

$=(5 \mathrm{~V} / 2) / 0.0707 \mathrm{~A}=2,5 \mathrm{~V} / 0,0707 \mathrm{~A}=35.4 \Omega$ $35.4 \Omega$ bukan nilai resistor umum. Nilai terdekat dari kedua sisi $35 \Omega$ adalah 30 dan $40 \Omega$. Selalu pilih nilai yang lebih kecil, atau arus beban maksimum akan membuat tegangan lebih tinggi dari AREF. Semakin jauh dari nilai ideal, semakin rendah akurasinya. Sehingga pada kasus ini digunakan burden resistor dengan nilai $33 \Omega$.

Pada proses pemerograman pada modul mikrokontroler yang dibutuhkan pada sistem ini yaitu Arduino Uno yang digunakan untuk membuat program serta melakukan kontrol secara keseluruhan yang nantinya akan menampilkan nilai hasil pengkuran dari modul, sensor arus invasive ACS712, dan sensor arus non invasive SCT013. Dari program tersebut nilai dari kalibrasi yang sesui dengan alat ukur digital clamp meter kita masukkan nilai kalibrasi sebesar 22 untuk sensor arus non invasive SCT013 dan nilai kalibrasi sebesar 0.00096 untuk sensor arus invasive ACS712. Berikut tampilan program untuk pembacaan arus disistem Arduino Uno untuk sensor arus non invasive SCT013, kemudian dibawahnya diikuti dengan pembacaan arus dari sensor arus invasive ACS712 pada sistem Arduino Uno:

$\begin{array}{ll}\text { \#include "EmonLib.h" } & \text { // Include Emon } \\ \text { Library } & \text { EnergyMonitor emon1; } \\ \text { instance } & \text { // Create an } \\ \text { void setup() } & \\ & \text { Serial.begin(9600); }\end{array}$




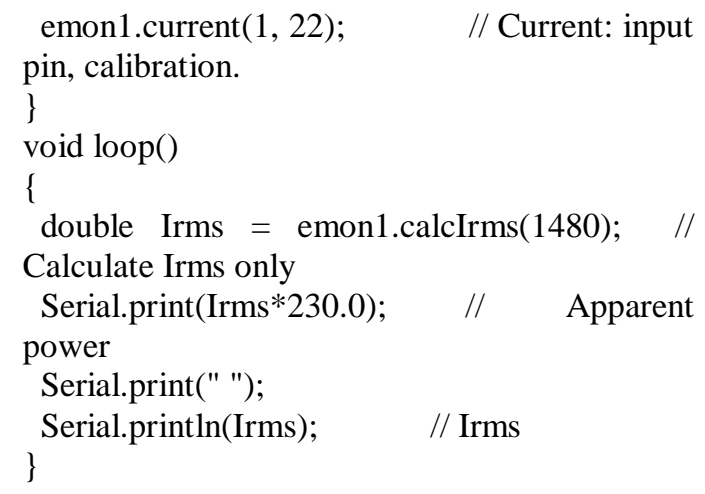

Berikut tampilan program untuk pembacaan arus disistem Arduino Uno untuk sensor sensor arus invasive ACS712:

\#define SAMPLES 300

\#define ACS_Pin A0

float High_peak,Low_peak;

float Amps_Peak_Peak, Amps_RMS;

void setup()

\{

Serial.begin(9600); pinMode(ACS_Pin,INPUT);

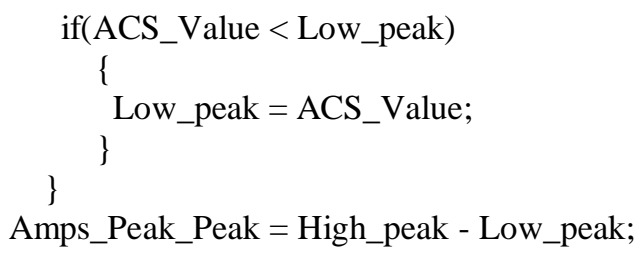

Proses kalibrasi sensor dilakukan agar didapatkan nilai pembacaan nilai arus yang lebih tepat setiap satuan persentase arus yang terbaca dan juga mengetahui tingkat akurasi pada sensor arus invasive ACS712 dan sensor arus non invasive SCT013. Pengujian dimulai dengan memasang rangkaian pada Gambar 8 dan Gambar 9, kemudian memberikannya program.

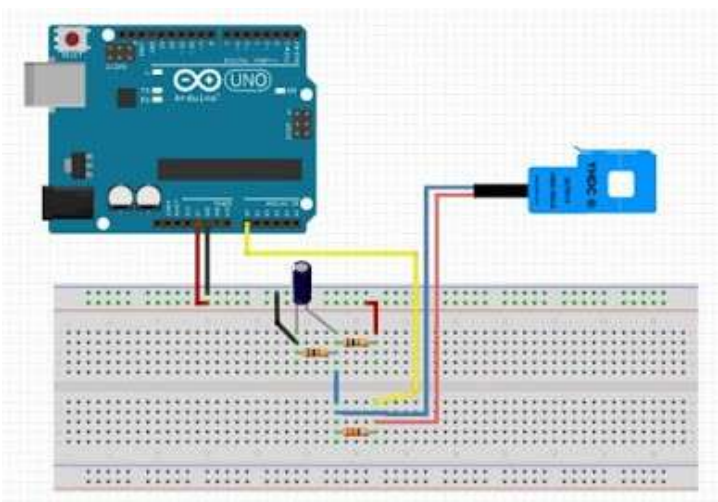

Gambar 8 Rangkaian sensor arus non invasive SCT013

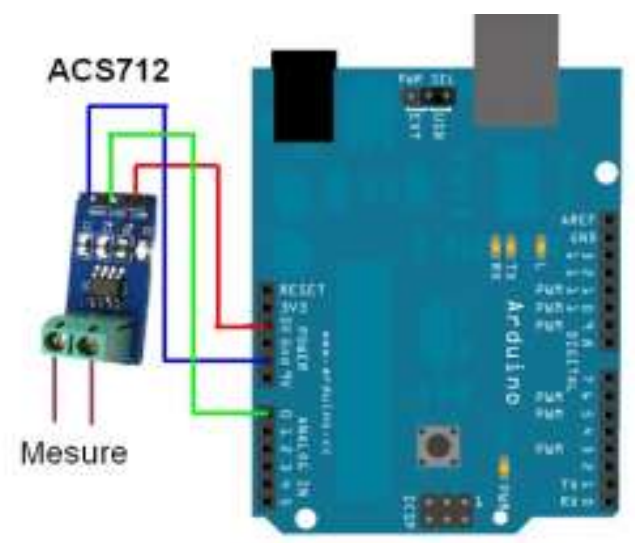

Gambar 9 Rangkaian sensor arus invasive ACS712

Kalibrasi sensor dilakukan dengan mengambil salah satu sample dari sensor arus non invasive SCT013 maupun sensor arus invasive ACS712 kemudian membandingkannya dengan pembacaan alat ukur digital clamp meter. Pengujian dilakukan dalam keadaan tanpa beban atau beban nol. Kemudian mengamati perubahan keluaran nilai arus. 


\section{HASIL DAN PEMBAHASAN}

A. Implementasi Perangkat Keras

Implementasi perangkat keras pada sistem ini dimulai dari menghubungkan semua komponen yang dibutuhkan dalam membangun sistem monitoring. Tampilan perangkat keras sistem monitoring sensor arus Non Invasive SCT013 dan sensor arus Invasive ACS712 dengan mikrokontroller arduino dapat dilihat pada Gambar 10 dan Gambar 11 merupakan implementasi sistem sistem monitoring arus dengan sensor arus Non Invasive SCT013 dan sensor arus Invasive ACS712. Terlihat bahwa prototype sistem ini hanya menggunakan komponen yang minim sehingga tidak akan memakan banyak tempat ketika dihubungkan dengan stop kontak.

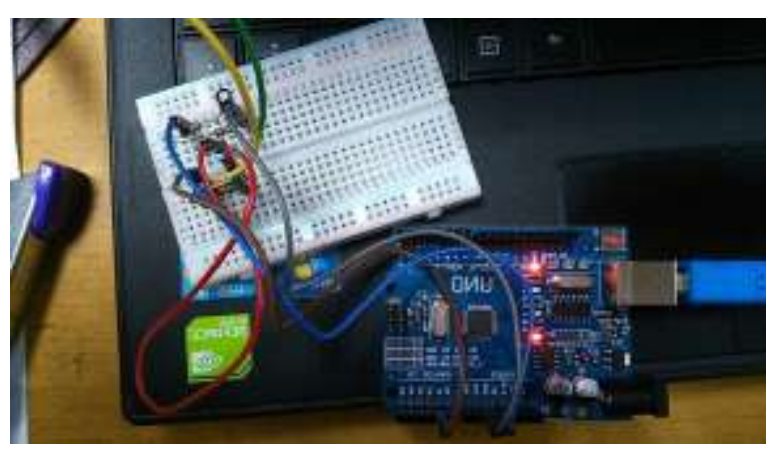

Gambar 10. Implementasi Perangkat Keras Sensor Arus Non Invasive SCT013

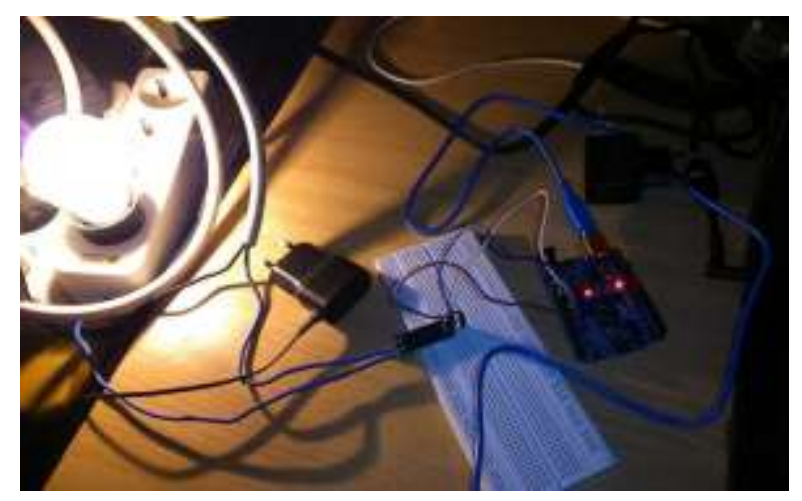

Gambar 11. Implementasi Perangkat Keras Sensor Arus Invasive ACS712

B. Pengujian Sensor Arus Invasive ACS712 dan Sensor Arus Non Invasive SCT013

Perbandingan atau pengujian arus antara sensor arus non invasive SCT013, sensor arus invasive ACS712, dan Digital Clamp Meter dapat dilihat pada Tabel 4.1.
Tabel 1 Pengujian Perbandingan Sensor Arus Non Invasive SCT013, Sensor Arus Invasive ACS712 dengan Digital Clamp Meter

\begin{tabular}{|c|c|c|c|c|}
\hline NO & Beban & $\begin{array}{c}\text { digital } \\
\text { clamp } \\
\text { meter (A) }\end{array}$ & $\begin{array}{c}\text { Sensor } \\
\text { Arus } \\
\text { SCT013 (A) }\end{array}$ & $\begin{array}{c}\text { Sensor } \\
\text { Arus } \\
\text { ACS712 (A) }\end{array}$ \\
\hline 1 & $\begin{array}{c}\text { Lampu LED } \\
5 \text { W }\end{array}$ & 0.04 & 0.05 & 0.07 \\
\hline 2 & $\begin{array}{c}\text { Lampu LED } \\
7 \text { W }\end{array}$ & 0.04 & 0.04 & 0.06 \\
\hline 3 & $\begin{array}{c}\text { Lampu LED } \\
11 \text { W }\end{array}$ & 0.05 & 0.06 & 0.07 \\
\hline 4 & $\begin{array}{c}\text { Lampu } \\
\text { PIJAR 25W }\end{array}$ & 0.08 & 0.08 & 0.09 \\
\hline 5 & PC & 0.23 & 0.23 & 0.24 \\
\hline 6 & Charger HP & 0.04 & 0.05 & 0.08 \\
\hline 7 & Dispanser & 0.18 & 0.19 & 0.15 \\
\hline 8 & $\begin{array}{c}\text { Laptop 12 } \\
\text { Inch }\end{array}$ & 0.12 & 0.12 & 0.12 \\
\hline
\end{tabular}

Berdasarkan pengambilan data besaran arus yang sudah didapatkan melalui alat sensor arus non invasive SCT013, sensor arus invasive ACS712 dan digital clamp meter pada Tabel 1, maka dapat kita susun grafik perbandingan sensor arus non invasive SCT013, sensor arus invasive ACS712 terhadap digital clamp meter sesuai dengan Gambar 12.

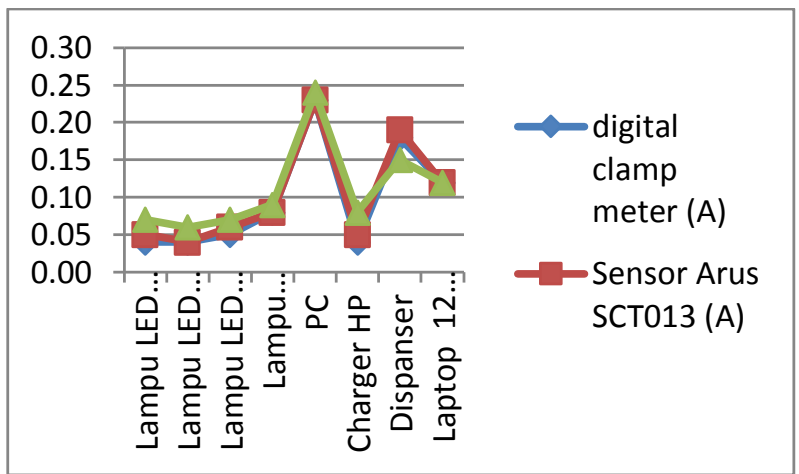

Gambar 12. Grafik Perbandingan Sensor Arus Non Invasive SCT013, Sensor Arus Invasive ACS712 dengan Digital Clamp Meter.

Dari hasil pengukuran pada Tabel 1 bahwa pada sensor arus Non Invasive SCT013 dan Sensor Arus Invasive ACS712 ini sudah bekerja dengan baik. Hal tersebut dapat dibuktikan dengan menggunakan Digital Clamp Meter pada beban yang terpasang. Misal pada beban Lampu LED 5 Watt sensor arus Non Invasive SCT013 arus yang terukur adalah 0,05 ampere, pada sensor arus Invasive ACS712 arus yang terukur adalah 0,07 ampere sedangkan hasil pengukuran pada Digital Clamp Meter adalah 0,04 Ampere. Hasil pengukuran tersebut menunjukkan bahwa alat prototipe sudah dapat 


\section{Analisis Sensor Arus Invasive ACS712 dan Sensor Arus Non Invasive SCT013 Berbasis Arduino}

digunakan sebagai alat monitoring arus pada beban listrik.

Gambar 13 menerangkan proses pengambilan data dengan sensor arus non invasive SCT013 dan digital clamp meter pada beban yang dihubungkan dengan arduino, pada Gambar 13 juga menerangkan hasil pembacaan sensor SCT013 dan coding yang dipakai untuk menjalankan proses perhitungan pada mikrokontroller arduino.

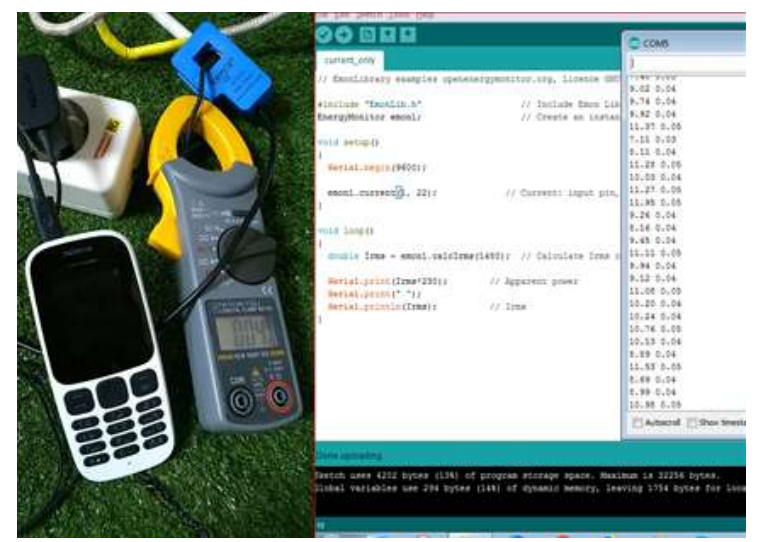

Gambar 13. Percobaan Pengukuran digital clamp meter dan Sensor Arus Non Invasive SCT013

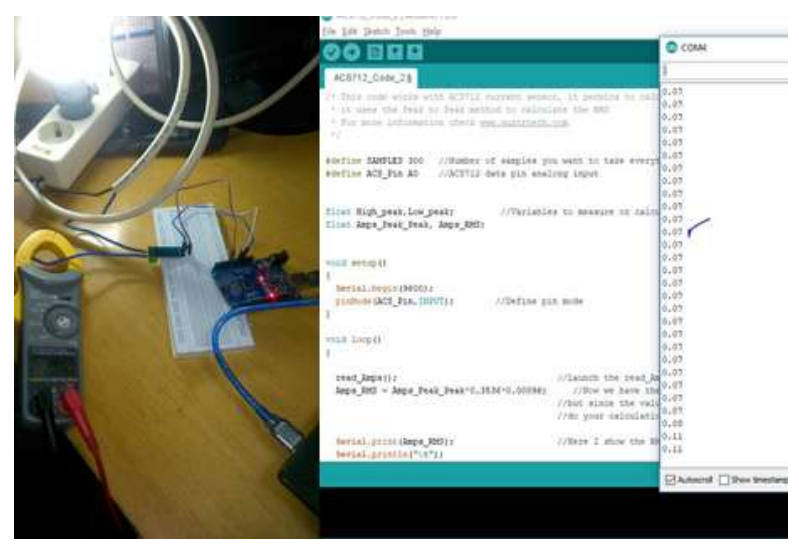

Gambar 14. Percobaan Pengukuran digital clamp meter dan Sensor Arus Invasive ACS712

Gambar 14 menerangkan proses pengambilan data dengan sensor arus invasive ACS712 dan digital clamp meter pada beban yang dihubungkan dengan arduino, pada Gambar 14 juga menerangkan hasil pembacaan sensor ACS712 dan coding yang dipakai untuk menjalankan proses perhitungan pada mikrokontroller arduino

Error pada pengukuran pada sensor arus Non Invasive SCT013 dan Sensor Arus Invasive ACS712 terhadap digital clamp meter dapat dihitung dengan rumus sebagai berikut :

$\%$ Error $=[($ Nilai terbaca - Nilai sebenarnya $)] /$ Nilai terbaca $\mathrm{x} 100 \%$

Dari perhitungan diatas didapatkan rata-rata error pada masing-masing beban untuk lampu LED 7 Watt sebesar $0 \%$. Untuk pengukuran sensor arus Non Invasive SCT013 terhadap digital clamp meter. Sedangkan untuk hasil pengujian perangkat beban yang lain dapat dilihat pada Tabel 2.

Tabel 2 Hasil pengujian persentase kesalahan dari pengukuran sensor arus Invasive ACS712, sensor arus Non Invasive SCT013 terhadap digital clamp meter.

\begin{tabular}{|c|l|c|c|c|c|c|}
\hline NO & Beban & $\begin{array}{c}\text { digital } \\
\text { clamp } \\
\text { meter } \\
(\mathbf{A})\end{array}$ & $\begin{array}{c}\text { Sensor } \\
\text { Arus } \\
\text { SCT013 } \\
(\mathbf{A})\end{array}$ & $\begin{array}{c}\text { Sensor } \\
\text { Arus } \\
\text { ACS712 } \\
(\mathbf{A})\end{array}$ & $\begin{array}{c}\text { Error } \\
\text { SCT013 } \\
(\%)\end{array}$ & $\begin{array}{c}\text { Error } \\
\text { ACS712 } \\
(\%)\end{array}$ \\
\hline 1 & $\begin{array}{l}\text { Lampu } \\
\text { LED 5 W }\end{array}$ & 0.04 & 0.05 & 0.07 & $20 \%$ & $43 \%$ \\
\hline 2 & $\begin{array}{l}\text { Lampu } \\
\text { LED 7 W }\end{array}$ & 0.04 & 0.04 & 0.06 & $0 \%$ & $33 \%$ \\
\hline 3 & $\begin{array}{l}\text { Lampu } \\
\text { LED 11 W }\end{array}$ & 0.05 & 0.06 & 0.07 & $17 \%$ & $29 \%$ \\
\hline 4 & $\begin{array}{l}\text { Lampu } \\
\text { PIJAR } \\
\text { 25W }\end{array}$ & 0.08 & 0.08 & 0.09 & $0 \%$ & $11 \%$ \\
\hline 5 & PC & 0.23 & 0.23 & 0.24 & $0 \%$ & $4 \%$ \\
\hline 6 & $\begin{array}{l}\text { Charger } \\
\text { HP }\end{array}$ & 0.04 & 0.05 & 0.08 & $20 \%$ & $50 \%$ \\
\hline 7 & Dispanser & 0.18 & 0.19 & 0.15 & $5 \%$ & $-20 \%$ \\
\hline 8 & $\begin{array}{l}\text { Laptop 12 } \\
\text { Inch }\end{array}$ & 0.12 & 0.12 & 0.12 & $0 \%$ & $0 \%$ \\
\hline
\end{tabular}

Dari hasil pengujian pada Tabel 2, tampak ketelitian sensor arus Non Invasive SCT013 lebih akurat dibandingkan dengan sensor arus Invasive ACS712. Dimana hasil pengukuran yang ditunjukan oleh sensor arus Non Invasive SCT013 hampir mendekati pada alat digital clamp meter yang digunakan, walaupun hasil pengukuran dari sensor arus Invasive ACS712 masih jauh selisihnya dengan pembacaan dari digital clamp meter namun dapat penulis sampaikan hasil pengukuran antara sensor Invasive dan digital clamp meter sudah mendekati. Misal pada beban lampu LED 11 Watt sensor arus yang terukur pada alat prototype sensor sensor arus Non Invasive SCT013 adalah 0,06 A, pada alat prototype sensor arus Invasive ACS712 adalah 0,07 A sedangkan pada digital clamp meter adalah 0,05 A. Yang berarti error pada pengukuran pada sensor arus Non Invasive SCT013 dan sensor arus Invasive ACS712 terhadap digital clamp meter sudah mendekati.

\section{KESIMPULAN}

Berdasarkan pada tahapan penelitian yang dilakukan mulai dari perancangan hardware, perancangan software, implementasi, hingga tahap 


\section{Analisis Sensor Arus Invasive ACS712 dan Sensor Arus Non Invasive SCT013 Berbasis Arduino}

pengujian perangkat monitoring arus pada beban listrik rumah tangga dapat ditarik kesimpulan dan saran yaitu pembacaan alat ukur dengan satu buah sensor arus tidak bisa memberikan informasi yang akurat akan konsumsi arus yang terpakai pada suatu rangkaian beban, perlu adanya pembanding dari sensor dengan tipe yang berbeda untuk mengetahui tingkat keakurasiannya. Hasil dari persentase error keseluruhan yg diperoleh dari perbandingan sensor arus Non Invasive SCT013 adalah $62 \%$ dan sensor arus Invasive ACS712 adalah $150 \%$. Dengan kondisi pembacaan masing masing sensor arus Non Invasive SCT013 dan sensor arus Invasive ACS712, sensor arus Non Invasive SCT013 lebih mendekati pembacaan alat digital clamp meter. Sehingga sensor arus Non Invasive SCT013 bisa menjadi salah satu pilihan sensor arus dalam penggunaan monitoring energy listrik.

\section{DAFTAR PUSTAKA}

[1] Artanto, Dian., (2012). Interaksi Arduino dan LabVIEW. Jakarta : Gramedia.

[2] B G Melipurwobo (2016). Pengukuran Daya Listrik Real Time dengan Menggunakan Sensor Arus ACS712. ORBITHVOL. 12 NO. 1 MARET $2016: 17-23$

[3] Current sensor ICs, ACS712, Available, (Online). (http://www.allegromicro.com/ diakses 10 Maret 2020)

[4] Diah Risqiwati, Ahmad Ghozali, Zamah Sari (2016). Rancang Bangun Sistem Monitoring Listrik Prabayar dengan Menggunakan Arduino Uno. KINETIK, Vol.1, No.2, Agustus 2016, Hal. 47-54

[5] Goklas Franz Michael Tambun (2017). Kalibrasi Tegangan pada Wattmeter dengan Sensor Arus Seri ACS712 Berbasis Mikrokontroller ATM 8535, Tugas Akhir Fakultas Matematika dan Ilmu Pengetahuan Alam Universitas Sumatera Utara Medan

[6] How to Build an Arduino Energy Monitor - Measuring Mains Current Only-SCT013, (online) (https://learn.openenergymonitor.org/diakses 15 Maret 2020

[7] Ignatius I Wayan Rexci Indra Parmana, Cok Gede Indra Partha, Ngakan Putu Satriya Utama (2018). Rancang Bangun Sistem Monitoring Arus Beban pada Gardu Distribusi Menggunakan Short Message Service. Majalah Ilmiah Teknologi Elektro, Vol. 17, No. 1,Januari -April 2018 DOI: https://doi.org/10.24843/MITE.2018.v17i01.P03

[8] Rini Sulistyowati dan Dedi Dwi Febriantoro (2012). Perancangan Prototype Sistem Control dan Monitoring Pembatas Daya Listrik Berbasis Mikrokontroler. Jurnal IPTEK Vol 16 No.1 Mei 2012

[9] Wayan Arsa Suteja, Made Adi Surya (2019). Sistem Pencatatan Pemakaian Listrik Menggunakan Aplikasi Arduino. Jurnal Protek, Volume 06, No.2 September 2019 